\title{
First field observation of the predation by Jaguar (Panthera onca) on Olive Ridley sea turtle (Lepidochelys olivacea) at Nancite Beach, Santa Rosa National Park, Costa Rica
}

\author{
Sergio Escobar-Lasso \\ Instituto Internacional en Conservación y Manejo de Vida Silvestre. ICOMVIS. Universidad Nacional de Costa Rica, \\ Heredia, Costa Rica \& Fundación R.A.N.A. (Restauración de Ambientes Neotropicales Alterados), Heredia, Costa Rica. \\ biosergiobike@gmail.com \\ Luis G. Fonseca \\ Wilbert N. Villachica \\ Biocenosis Marina, Trinidad de Moravia, San José, Costa Rica. \\ Hansel Herrera \\ Instituto Internacional en Conservación y Manejo de Vida Silvestre. ICOMVIS. Universidad Nacional de Costa Rica, \\ Heredia, Costa Rica. \\ Roldán A. Valverde \\ Department of Biological Sciences, Southeastern Louisiana University, Hammond, Louisiana, USA. \\ Wagner Quirós-Pereira \\ Marta Pesquero \\ Biocenosis Marina, Trinidad de Moravia, San José, Costa Rica. \\ Pamela T. Plotkin \\ Texas A\&M University, Department of Oceanography, College Station, Texas, USA.
}

Jaguars have been recorded preying on adult female sea turtles on their nesting beaches in Costa Rica, Guyana, Mexico and Suriname (Fretey 1977, Autar 1994, Cuevas et al. 2014, Guildera et al. 2015). Jaguars prey on Green (Chelonia mydas), Olive Ridley (Lepidochelys olivacea), Hawksbill (Eretmochelys imbricata), and Leatherback (Dermochelys coriacea) sea turtles (see Fretey 1977, Autar 1994, Carrillo et al. 1994, Chinchilla 1997, Tröeng 2000, Heithaus et al. 2008, Veríssimo et al. 2012, Arroyo-Arce et al. 2014, Cuevas et al. 2014, Arroyo-Arce \& Salom-Pérez 2015, Guildera et al. 2015). The capture effort and risk of injury associated with the predation of nesting sea turtles is expected to be lower relative to other prey species in the jaguar's diet (Caval canti \& Gese2010). Additionally, they can be key resources when other prey availability is low (Veríssimo et al. 2012).

All published literature related to the predation of sea turtles by Jaguars document sightings of carcasses discovered the day after the kill by diurnal patrols on the beach. The capture and predation of a sea turtle by a Jaguar has never been described in scientific literature (see Fretey 1977, Autar 1994, Carrillo et al. 1994, Chinchilla 1997, Tröeng 2000, Heithaus et al. 2008, Veríssimo et al. 2012, Arroyo-Arce et al. 2014, Cuevas et al. 2014, Arroyo-Arce \& Salom-Pérez 2015, Guildera et al. 2015) and to our knowledge, has never been observed directly. Guildera et al. (2015) discovered a recently predated Green sea turtle dragged a few meters into the vegetation of the beach at Tortuguero National Park; however, they did not observe the exact moment when the predation occurred. Therefore, the aim of this paper is to report for the first time the detailed field observation of the capture and predation of an Olive Ridley Turtle by a Jaguar at Nancite Beach, Santa Rosa National Park, Costa Rica.

The field observation occurred during an arribada (massive turtle arrival) on September $14^{\text {th }} 2014$, in one of the most important nesting beaches, the Nancite beach in Santa Rosa National Park (38,628 ha), located in the Guanacaste Province, Northwest Pacific coast of Costa Rica $\left(10^{\circ} 48^{\prime} \mathrm{N}\right.$ and $85^{\circ} 39^{\top} \mathrm{W}$; Figure 1). This predation event was filmed and photographed by a member of our team (W. N. Villachica) during a beach patrol (Figure 2). The video recording was made approximately one meter from the jaguar, thus it is uncertain if the behavior of the jaguar was affected by this fact. During the event an adult

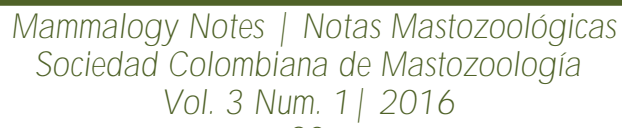


jaguar male was observed walking along the beach (Figure 2A) and a few minutes later, the Jaguar captured a nesting turtle which was located about nine meters of the vegetation line on the upper beach. The Jaguar bit the neck of the turtle and dragged it to the edge of the beach vegetation. Subsequently, the Jaguar began to bite and break the carapace of the turtle on the right rear (Figure 2B, C, D). This caused a heavy bleeding to the turtle and the jaguar started to drink the blood (Figure $2 \mathrm{E}, \mathrm{F}, \mathrm{G}$ ). Then, the Jaguar began to selectively eat the muscle of the right rear flipper (Figure $2 \mathrm{H}, \mathrm{I}$ ) and after completely consuming it the Jaguar started to eat the flipper and neck's fatty tissues (Figure 2], K). Afterwards, the jaguar moved away from the turtle (Figure 2L). It is noteworthy that at the time the Jaguar moved away, the turtle was still alive but died a few minutes later. After the jaguar abandoned the turtle carcass, W. N. Villachica observed the felid killing three more turtles the same night. However, these events could not be filmed or photographed. Nevertheless, the jaguar's behavior was the same. The four turtles killed by the jaguar were left on the beach and were eaten the next day by black vultures (Coragyps atratus) and turkey vultures (Cathartes aura).

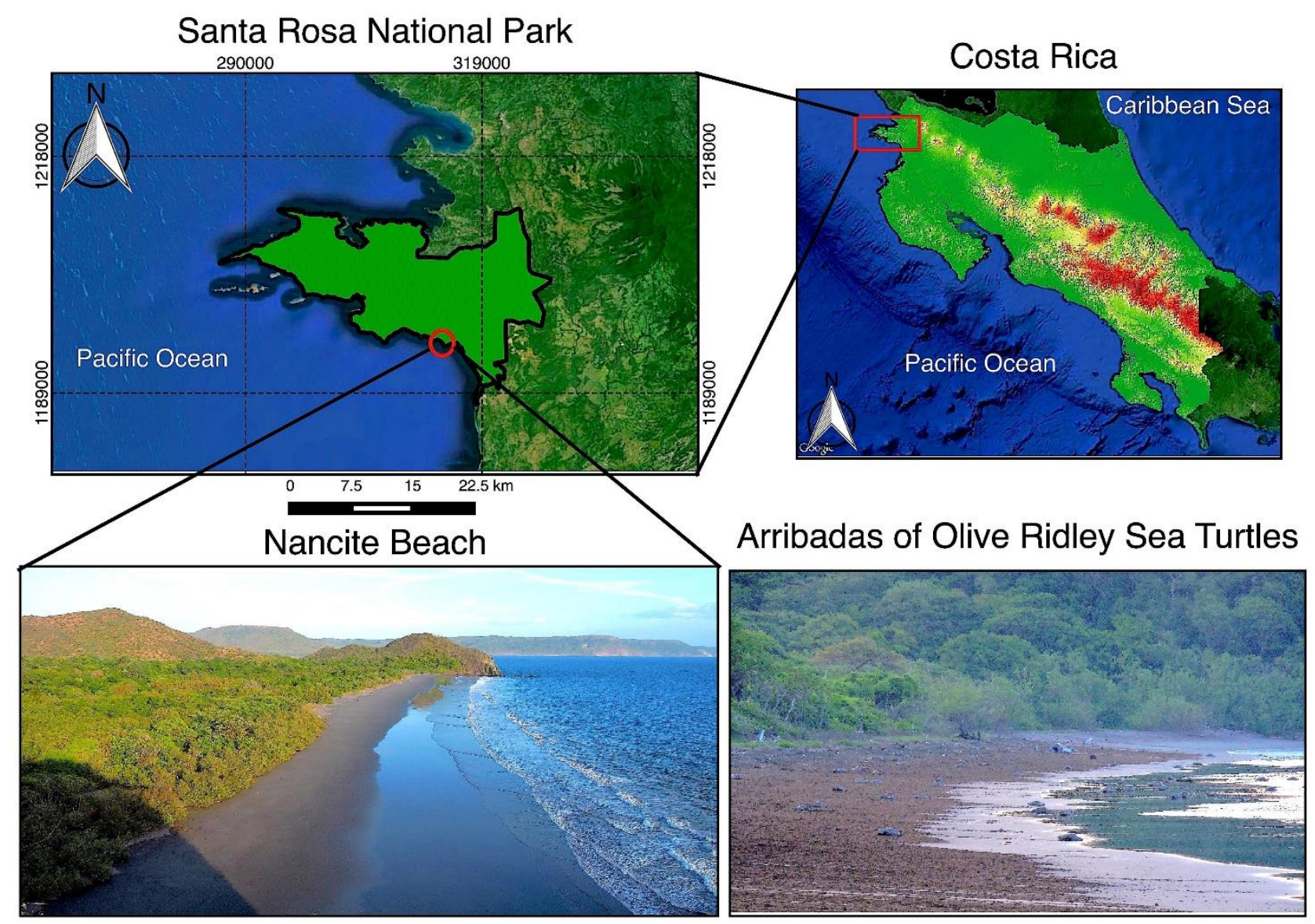

Figure 1. Location of Nancite Beach, Santa Rosa National Park, Guanacaste Province, Costa Rica. Nancite Beach is an important rookery where Olive Ridley sea turtle (Lepidochelys olivacea) aggregate to nest synchronously during arribadas.

One interesting aspect of this field observation is that W. N. Villachica was standing at one meter from the Jaguar during this event, and the jaguar did not flee or show sign of aggressiveness. Although this seems to be an unusual behavior for a wild Jaguar, we believe that this individual became accustomed to Villachica because he lived and worked in Nancite for five consecutive years. Villachica also recorded another close encounter on July $26^{\text {th }} 2014$, this time involving an adult Jaguar female (see https://www.youtube.com/watch?v=1SW0zyn0t4E). The cases of wild mammals becoming accustomed to the presence of a researcher are scarce. However, other similar cases in other mammalian species have been reported (Fossey 1983, Goodall 1986, Ellis 2009, Richardson 2009). 


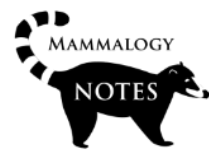

MAMMALOGY NOTES| NOTAS MASTOZOOLOGICAS

ISSN 2382-3704

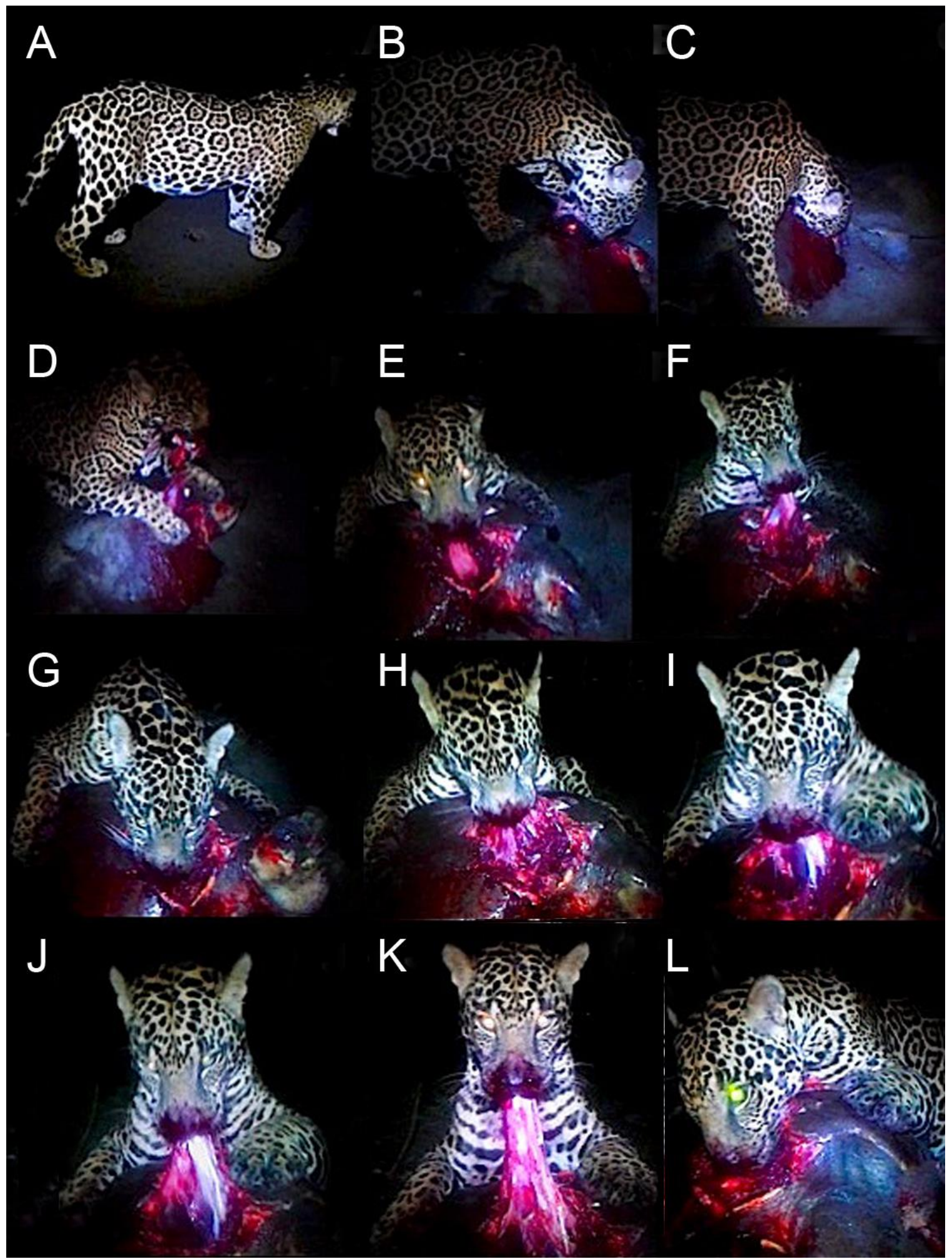

Figure 2. Field observation of the predation of an Olive Ridley sea turtle (Lepidochelys olivacea) by the Jaguar (Panthera onca) at Nancite beach, Costa Rica. Part of the predation event can be seen on YouTube (https://www.youtube.com/watch?v=14q0PAuCeZM\&feature=youtu.be).

Mammalogy Notes | Notas Mastozoológicas

Sociedad Colombiana de Mastozoología Vol. 3 Num. 1| 2016 
In the predation event described here, the jaguar killed four Olive Ridleys on the same night. The behavior of killing several preys on the same night had already been registered in Puma concolor. For example, in the Andean region of Colombia it has been documented that a single individual of $P$. concolor can kill up to 15 sheep in one night (Escobar-Lasso et al. 2014). However, these hunted animals were domestic animals, therefore it is uncertain whether this behavior occurs in wild prey. To our knowledge this behavior has never been recorded in jaguars. Verissimo et al. (2012) and Guildera et al. (2015) observed Jaguar behavior in Tortuguero that could partly explain our observation. They discovered that the number of predated Green sea turtles (Chelonia mydas) is significantly greater during the peak-nesting season, but kills were often abandoned without concealment and generally showing only partial consumption occurred on the night of the kill. Something similar happens at Nancite during arrivals. With many turtles nesting on the beach at the same time, the Jaguar can kill several individuals and feeding on them partially searching only for the rich muscle tissues. By doing so the Jaguar possibly decreases the extra energy demand of breaking the wholetortoise's carapace to reach other internal muscles and main organs.

\title{
Acknowledgements
}

We thank Margarita Gil-Fernández for helping with the revision of the spelling and grammar of the English language. We express our sincere thanks to Roger Blanco, for providing the research passport.

\section{References}

ARROYO-ARCE, S. \& R. SALOM-PÉREZ. 2015. Impact of Jaguar Panthera onca (Carnivora: Felidae) predation on marine turtle populations in Tortuguero, Caribbean coast of Costa Rica. Biología Tropical 63: 815-825.

ARROYO-ARCE, S., et al. 2014. Habitat features influencing Jaguar Panthera onca (Carnivora: Felidae) occupancy in Tortuguero National Park, Costa Rica. Revista de Biología Tropical 62: 1449-1458.

AUTAR, L. 1994. Sea turtles attacked and killed by Jaguars in Suriname. Marine Turtle Newsletter 67: 11-12.

CAVALCANTI, S. \& M. GESE. 2010. Kill rates and predation patterns of Jaguars (Panthera onca) in the southern Pantanal, Brazil. Journal of Mammalogy 91: 722-736.

CARRILLO, E., et al. 1994. Depredación de tortuga lora (Lepidochelys olivacea) y de tortuga verde (Chelonia mydas) por el Jaguar (Panthera onca). Vida Silvestre Neotropical 3: 48-49.

CHINCHILLA, F. A. 1997. La dieta del Jaguar (Panthera onca), el puma (Felis concolor) y el manigordo (Felis pardalis) en el Parque Nacional Corcovado, Costa Rica. Revista de Biologia Tropical 45: 1223-1229.

CUEVAS, E., et al. 2014. Marine turtles and Jaguars: two mystical species coexisting on the coast of Quintana Roo, México. Retrieved from http://casablancafishing.com/wpcontent/uploads/2013/07/Jaguars-and-Marine-Turtles.pdf

ELLIS, S. 2009. The Man Who Lives with Wolves. HarperCollins. 250 pp.

ESCOBAR-LASSO, S., et al. 2014. Los felinos silvestres del departamento de Caldas, en la región andina de Colombia: composición, distribución y conservación. Therya 5: 575588.

FOSSEY, D. 1983. Gorillas in the Mist. Houghton Mifflin Company. $350 \mathrm{pp}$.

FRETEY, J. 1977. Cuases de motalite des tortues luth adults (Dermochelys coriacea) sur le littoral guayanais. Courrier de la Nature 52: 257-266.

GOODALL, J. 1986 The Chimpanzees of Gombe: Patterns of Behavior. Harvard University Press, Boston. 400 pp.

GUILDERA, J., et al. 2015. Jaguars (Panthera onca) increase kill utilization rates and share prey in response to seasonal fluctuations in nesting green turtle (Chelonia mydas mydas) abundance in Tortuguero National Park, Costa Rica. Mammalian Biology 80: 65-72.

HEITHAUS, M. R., et al. 2008. A review of lethal and non-lethal effects of predators on adult marine turtles. Journal of Experimental Marine Biology and Ecology 356: 43-51. RICHARDSON, K. 2009. Part of the Pride: My Life Among the Big Cats of Africa. St Martins Pr Inc. 243 pp.

TROËNG, S. 2000. Predation of green (Chelonia mydas) and leatherback (Dermochelys coriacea) turtles by Jaguar (Panthera onca) at Tortuguero National Park, Costa Rica. Chelonian Conservation and Biology 3: 751-753.

VERÍSSIMO, D., et al. 2012. Jaguar Panthera onca predation of marine turtles: conflict between flagship species in Tortuguero, Costa Rica. Oryx $46: 340-347$.

\author{
Mammalogy Notes | Notas Mastozoológicas \\ Sociedad Colombiana de Mastozoología \\ Vol. 3 Num. 1| 2016
}

